$$
\text { CONF- } 9406405-1
$$

\title{
TOWARD MORE UNIFORM ENVIRONMENTAL ETHICS: SCIENCE CAN HELP POLICYMAKING FOR ELECTROMAGNETIC FIELD EXPOSURES
}

\author{
Clay E. Easterly Ph.D. \\ Health Effects Group Leader \\ Oak Ridge National Laboratory ${ }^{1,2}$ \\ Oak Ridge, TN USA 37831-6101 \\ $\mathrm{P}(615)-574-6254 ; \mathrm{F}(615)-576-7651$
}

$b i=0$

MAV 060 1

The translation of scientific information to public policy is rarely a simple task even when the information is relatively well understood. When there is great uncertainty in the information, as in the case of low frequency electromagnetic fields (EMFs), this process becomes very difficult for most countries. I believe that everyone participating in this forum can agree on the value of bringing the understandings of science closer to the political decisionmaking process. The question is how? I would suggest that the solution may be found in looking at the issue of environmental risk from a different perspective than is currently done (especially within the USA).

If policy makers attempt to work from first principles with each hazardous agent, for each possible medium, (i.e., air, water, food) separately, there is bound to be confusion because of differing levels of accurate information for each agent/medium combination. The state of science is such at present that we understand the hazards and risks to humans relatively well for only a few environmental agents. For most environmental agents, we have much less well developed information, and often it exists only for laboratory animals and in vitro assays. If one of the goals of public policy is to minimize harm to humans from environmental agents, it would seem that a reasonable framework could be constructed around the concept of comparative hazard/risk. And further, that this comparative hazard/risk could develop from a cumulative knowledge

\footnotetext{
${ }^{1}$ Managed by Martin Marietta Energy Systems, Inc., for the U.S. Department of Energy under contract DE-AC05-84OR21400.

2"The submitted manuscript has been authored by a contractor of the U.S. Government under contract No. DE-AC05-840R21400. Accordingly, the U.S. Government retains a nonexclusive royalty-free license to publish or reproduce the published form of this contribution, or allow others to do so, for U.S. Government purposes."
}

\section{MASTER}

DISTRIBUTION OF THIS DOCUMENT IS UNLIMITED $\widehat{a}$ 
of environmental agents rather than considering each one from "first principles". Following this "first principles" concept for each toxicological hazard leads to a confused environmental ethic, and thus does not provide the political decision making process even within a single country a consistent perspective on hazard/risk. Is there any question then why there is an inconsistent environmental ethic seen around the globe?

In presenting information to the public and policy makers, a methodology based on comparative environmental risk would have several advantages over one based on evaluating absolute risks. The most obvious is that it would be easier to communicate possible harm from EMFs because comparison with familiar hazards would be an integral part of the evaluation. The public could then participate more knowledgeably in defining general directions of environmental regulatory science. A second very important advantage is that members of the public would have the opportunity to define the level of risk considered acceptable in terms of currently-experienced risks characterized in the assessment process. Actual execution of this process would differ widely among members of the international community because of differing value systems, political processes, and differing experiences with environmental risk factors.

My analysis to date of the cumulative EMF data suggests several things. First, there is likely to be little improvement to be made by additional epidemiological studies that fail to incorporate measurements of environmental/residential/occupational contaminants such as solvents, pesticides and other materials known or suspected to be hazardous. Second, promotion and/or progression types of experiments will soon identify appropriate animal models for EMF research. Third, sufficient data are available to begin to construct a comparative assessment of harm from EMFs in the context of presently identified environmental/residential/occupational hazards.

A challenge to the members of this Forum is to identify methods for communicating our findings to the public at large and subsequently to the policy makers so that we can better serve the people supporting our efforts. My thoughts in this regard are that a consistent environmental ethic can be encouraged by the development of a process that will lead to a better comprehensive understanding, by both the scientific community and the public in general, of the likely health risks from EMFs. The framework should be structured so that comparative environmental/residential/occupational health risk assessment is an integral part of the process. 


\section{DISCLAIMER}

This report was prepared as an account of work sponsored by an agency of the United States Government. Neither the United States Government nor any agency thereof, nor any of their employees, makes any warranty, express or implied, or assumes any legal liability or responsibility for the accuracy, completeness, or usefulness of any information, apparatus, product, or process disclosed, or represents that its use would not infringe privately owned rights. Reference herein to any specifie commercial product, process, or service by trade name, trademark, manufacturer, or otherwise does not necessarily constitute or imply its endorsement, recommendation, or favoring by the United States Government or any agency thereof. The views and opinions of authors expressed herein do not necessarily state or reflect those of the United States Government or any agency thereof. 